\title{
Effects of light quality on reproduction, growth and pigment content of Gracilaria birdiae (Rhodophyta: Gracilariales)
}

\author{
José Bonomi Barufi ${ }^{1}$, Félix L. Figueroa ${ }^{2}$, Estela M. Plastino ${ }^{3}$ \\ ${ }^{1}$ Departamento de Botânica, Centro de Ciências Biológicas, Universidade Federal de Santa Catarina, \\ 88040-970 Florianópolis, SC, Brazil. \\ ${ }^{2}$ Departamento de Ecología y Geología, Facultad de Ciencias, Universidad de Málaga, Campus de Teatinos, s/n, \\ 29071 Málaga, Spain. \\ ${ }^{3}$ Departamento de Botânica, Instituto de Biociências da Universidade de São Paulo, Rua do Matão 277, \\ 05508-900 São Paulo, SP, Brazil. E-mail: emplasti@usp.br
}

\begin{abstract}
Summary: Gracilaria species are the main source of agar worldwide. Since laboratory cultivation is an important means of sustaining such production, this study aimed to assess the influence of two fundamental strategies of physiological algae adjustment, photoacclimation and photomorphogenesis, on G. birdiae physiology. Specifically, the effects of different spectral light qualities on reproduction, growth, and pigment content in two distinct photoperiods (8 and 14 hours) were examined. Tetrasporophytes and gametophytes were submitted to different light qualities: white, green, red, and blue over the course of nine weeks. At the end of this period, chlorophyll $a$, allophycocyanin, phycocyanin, and phycoerythrin contents were analysed. Gametophytes showed reproductive structures only under monochromatic radiation. A stimulatory effect on tetrasporangium differentiation was mainly observed under red light, but this high fertility was negatively correlated with growth rate, i.e. algae cultivated under red light showed the lowest growth rate. However, while growth rates were higher in algae exposed to white light, they were similar to those observed in algae subjected to green light and 14 hours of daylight. PE was the predominant pigment, irrespective of light quality. Phycocyanin and phycoerythrin concentration increased when algae were cultivated under green and blue light. Therefore, considering future management prospects for G. birdiae mariculture, we suggest that red light could be utilized as a reproductive inductor to produce tetraspores. Furthermore, if the aim is to achieve high phycoerythrin content, continuous blue light could be applied during a short photoperiod. Indeed, the combination of different wavelengths could allow better economic resource exploitation.
\end{abstract}

Keywords: Gracilaria birdiae; growth; light quality; pigment content; photoacclimation; reproduction.

Efectos de la calidad de luz en la reproducción, crecimiento y contenido pigmentario de Gracilaria birdiae (Rhodophyta: Gracilariales)

Resumen: Las especies del género Gracilaria son la principal fuente de agar en el mundo. El desarrollo de técnicas de cultivo en laboratorio es importante para mejorar la producción, y por ello, este estudio tuvo como objetivo la evaluación de la influencia de dos estrategias de ajuste fisiológico de las algas, la fotoaclimatación y la fotomorfogénesis en $G$. birdiae. De modo más específico, se evaluaron los efectos de diferentes calidades espectrales de luz sobre la reproducción, crecimiento y contenido pigmentario bajo dos fotoperiodos ( 8 y 14 horas). Tetrasporofitos y gametofitos fueron sometidos a las siguientes calidades de luz: blanca (WH), verde (GR), rojo (RD) y azul (BL) a lo largo de nueve semanas. Al final del periodo, se analizaron los contenidos de clorofila $a(\mathrm{Chl} a)$, aloficocianina (APC), ficocianina (PC) y ficoeritrina (PE). Los gametofitos carecieron de estructuras reproductivas exclusivamente en radiación blanca. La diferenciación de tetrasporangios fue obtenida bajo estímulo de luz roja, pero fue negativamente correlacionado con las tasas de crecimiento (GRTs), presentando las tasas más bajas. Por otro lado, mientras las tasas de crecimiento fueron más altas en algas expuestas a luz WH, éstas fueron similares en algas mantenidas bajo luz GR y 14 horas de fotoperiodo. PE fue el pigmento predominante en G. birdiae, independientemente de la calidad de la luz aplicada. La concentración de PC y PE aumentaron cuando las algas recibieron luz GR y BL. De esa manera, considerando las perspectivas de manejo en la maricultura de G. birdiae, se sugiere que la luz roja puede ser utilizada como factor de inducción de la producción de tetrasporas. Por otro lado, las algas cultivadas en fotoperiodos cortos y luz BL alcanzaron altos contenidos de PE. La combinación de diferentes longitudes de onda puede permitir una mayor valorización en la explotación económica de los recursos algales.

Palabras clave: Gracilaria birdiae; crecimiento; calidad de luz; contenido pigmentar; fotoaclimatacción; reproducción.

Citation/Como citar este artículo: Barufi J.B., Figueroa F.L., Plastino E.M. 2015. Effects of light quality on reproduction, growth, and pigment content of Gracilaria birdiae (Rhodophyta: Gracilariales). Sci. Mar. 79(1): 15-24. doi: http://dx.doi. org/10.3989/scimar.04049.12A 
Editor: E. Ballesteros.

Received: March 3, 2014. Accepted: November 26, 2014. Published: February 23, 2015.

Copyright: (C) 2015 CSIC. This is an open-access article distributed under the Creative Commons Attribution-Non Commercial Lisence (by-nc) Spain 3.0.

\section{INTRODUCTION}

Light is primarily used as a source of energy, enabling organisms to adapt to a steadily changing environment. The utilization of light by an organism is regulated by a process known as photoacclimation, or chromatic adaptation, including mechanisms to avoid an excess of light energy, such as photoprotection (Falkowski and La Roche 1991) and mechanisms to take advantage of low irradiances in any given ambient lighting. Light can also be used as an environmental signal to control metabolic and reproductive processes (Rüdiger and Figueroa 1992). Monochromatic light can provide the signalling necessary to regulate algal metabolism, reproduction and growth (Dring 1988), prompting, in turn, a variety of photomorphogenetic strategies, such as the control of cell growth or induced enzymatic activation (Lüning 1992). Additionally, light can induce shade-avoiding plasticity (Monro and Poore 2005).

Marine red algae occur in environments subjected to wide variations of irradiance and spectral distribution, and their pigment contents are regulated by irradiance and light qualities. These responses may be the result of photomorphogenetic signalling processes with photoreceptor control that regulate growth and metabolism (Talarico and Maranzana 2000). Photosynthetic changes can result from an imbalance of photosystems, a difference in the rate at which photosystems turn over, a deficiency in the electron transport chain, or a major change in the spatial relationship between the two photosystem (Gantt 1990).

An increase in phycobiliprotein and chlorophyll $a(\mathrm{Chl} a)$ content was observed in Chondrus crispus cultivated under blue, red, and green light in comparison with white light controls (Franklin et al. 2001). Halymenia floresii optimized its growth rates under green light, inducing Chl $a$ and lutein synthesis, whereas blue and red light stimulated the accumulation of phycobiliproteins (Godínez-Ortega et al. 2008). Blue light also stimulated nitrogen assimilation and the accumulation of such $\mathrm{N}$-compounds as biliproteins (Figueroa et al. 1995a). These alterations in red alga pigment content may be related to the size and amount of chromophores, as well as the number, structure or size of phycobilisomes, which are modified to optimize light absorption (Kursar et al. 1983b, López-Figueroa and Niell 1989, 1991). Furthermore, the synthesis of chlorophyll and biliprotein can be regulated by phytochrome (red/far-red light) and blue light photoreceptors (López-Figueroa and Niell 1991). Other responses in macroalgae have been assigned to photoreceptors, such as blue light control of reproduction in Laminaria saccharina gametophytes and hair differentiation in Scytosiphon lomentaria (Dring and Lüning 1973). Blue light also induced reproductive responses of Petalonia fascia and $P$. zosterifolia and, in addition, erect axes were inducted by red light for these species (Lüning and Dring 1973). Lemanea germination was inhibited by blue light but this process was reverted by subsequent white light exposure (Thirb and Benson-Evans 1983).

Gracilaria species are the main source of agar and, as such, drive a market worth millions of dollars around the world (Armisén 1995). Gracilaria birdiae Plastino and E.C. Oliveira has shown higher potential for agar extraction, although only natural banks have been exploited (Plastino and Oliveira 2002). The species has been harvested in northeast Brazil near coastal communities, and the short time interval between one harvest and the next is not sufficient to permit the complete recovery of seaweed beds (Carneiro et al. 2011). This species occurs from the northeast $\left(3^{\circ} \mathrm{S}\right)$ to the southeast $\left(20^{\circ} \mathrm{S}\right)$ coast of Brazil (Plastino and Oliveira 2002), and its extreme populations are in geographical areas $2500 \mathrm{~km}$ apart. Fertility is commonly observed, with abundance of tetrasporophytes in comparison with gametophytes (Carneiro et al. 2011). Considering its geographic distribution and daily photoperiods (Brazilian National Institute for Space Research, http:// sonda.ccst.inpe.br/basedados/index.html), G. birdiae may be exposed to photoperiods ranging from 10.8 to $13.9 \mathrm{~h}$ in the winter and summer solstice, respectively.

In accordance with the importance of G. birdiae, studies under controlled conditions are imperative to provide information about the biology of the species. In the laboratory, different strains of $G$. birdiae were isolated from different regions of the Brazilian coast, from southeastern to northeastern regions (Costa and Plastino 2001, 2011, Plastino et al. 2004), and some studies have been performed to understand the phenotypic plasticity promoted by acclimation and adaptation processes (Ursi and Plastino 2001, Ursi et al. 2003, 2008, Ayres-Ostrock and Plastino 2014a,b). Life history has been completed in the laboratory, but tetrasporangium differentiation was only observed with cultivation in short daylight (10L:14D) and irradiance of $100 \mu \mathrm{mol}$ of photons $\mathrm{m}^{-2} \mathrm{~s}^{-1}$ (Costa and Plastino 2001). While these studies give some indication of photoperiodic influence on the fertility of G. birdiae, tetrasporangium differentiation could be induced by variation of irradiance and specific light qualities. Therefore, since it is advantageous to understand and manage the reproduction of $G$. birdiae in the laboratory for future seedling production in mariculture, we designed light-controlled experiments to choose the best induction conditions of fertility in both gametophytes and tetrasporophytes. Fertility, growth and pigment content were all monitored. These parameters provided information about the relationship between fertility 
and vegetative performance. Moreover, a comparative analysis between the isomorphic stages of life history of the species is presented.

\section{MATERIALS AND METHODS}

\section{Biological material}

Non-reproductive apical segments of tetrasporophytes and male and female gametophytes of Gracilaria birdiae Plastino and E.C. Oliveira were obtained from algal collections of the "Édison J. Paula" marine seaweed laboratory at the University of São Paulo, Brazil (Lourenço and Vieira 2004, Costa et al. 2012). Different individuals from the red wild type were utilized in this study. These algae were derived from a natural population of Paracuru ( $3^{\circ} 25^{\prime} 31^{\prime \prime} \mathrm{S}$ and $\left.39^{\circ} 01^{\prime} 29^{\prime \prime} \mathrm{W}\right)$, Ceará State, Brazil.

\section{General culture conditions}

Unialgal cultures were established from non-reproductive apical segments of tetrasporophytes and gametophytes of Gracilaria birdiae, as described by Plastino and Oliveira (1990). Standard culture conditions were as follows: $25 \pm 2{ }^{\circ} \mathrm{C}$, alternating aeration periods of 30 minutes, $400 \mathrm{ml}$ Erlenmeyer flasks, containing sterile seawater (salinity of 32) enriched with von Stosch medium (Ursi and Plastino 2001) diluted to 25\%. This enriched seawater was changed weekly. Each flask contained four apices (all tetrasporophytes or two male plus two female gametophytes). The recognition of sexual stage of gametophytes was possible because these algal sections were derived from original fertile individuals, male and female gametophytes (with cystocarps). After sexual recognition, they were cultivated in different flasks for two months to avoid fertilization and to assure absence of cystocarps. In general, initial mean fresh weight biomass per flask (average \pm standard deviation) was $14.6 \pm 1.2 \mathrm{mg}$; if each reproductive stage was considered separately, there was $14.3 \pm 1.2$ for tetrasporophytes, and $14.9 \pm 1.2 \mathrm{mg}$ of fresh weight for gametophytes. Three replicates were utilized.

\section{Experimental light treatments}

Experiments were conducted over the course of nine weeks in biochemical oxygen demand culture chambers (Fanem, $347 \mathrm{G}$ ), with tubes positioned vertically in the door. Two light: dark cycles (L:D) were tested: 14L:10D and 8L:16D. Four light qualities were utilized: white (WH), green (GR), red (RD) and blue (BL). The different light qualities were obtained from Daylight Osram 40W tubes with four acrylic plate filters (3 mm width): transparent for WH, green for GR, red for RD, and blue for BL. Each chamber was prepared to receive only one type of acrylic plate. These plate filters were inserted at the biochemical oxygen demand culture chamber door, between the tubes and the internal environment of the culture chamber. These plates were positioned in a way that the white light emitted by Daylight tubes was filtered and only

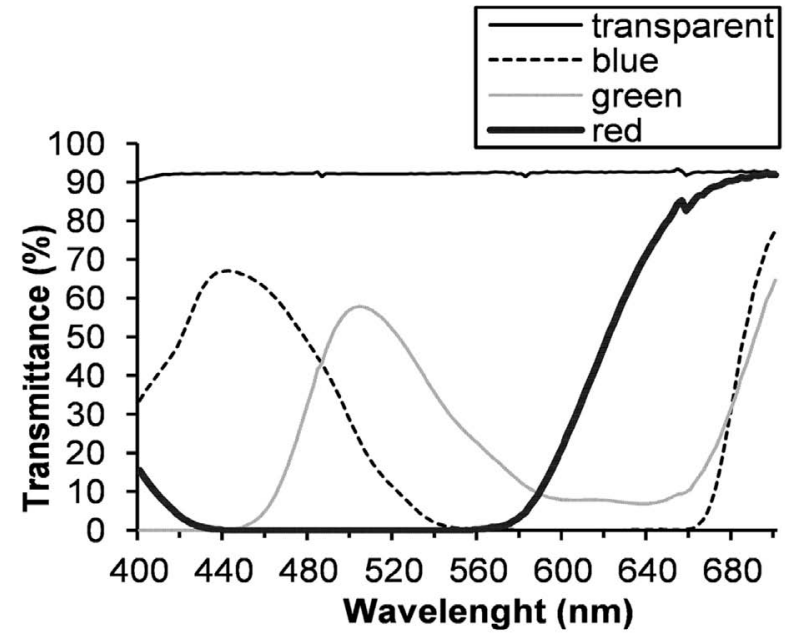

Fig. 1. - Spectral transmittance (\%) of broadband spectra of different light qualities obtained from a combination of lamps and acrylic filters: transparent (equivalent to white light), green, red, and blue.

specific wavelengths could achieve the Erlenmeyer flasks where algae were cultivated. These flasks were distributed in different positions of chamber, so as to receive similar amounts of irradiance. Light transmittances of these filtering acrylic systems were obtained in a spectrophotometer (HP 8452A) by positioning a piece of each acrylic plate in the place of the cuvette. These curves are shown in Figure 1.

Irradiances were measured with a Li-COR spherical sensor (Model Li-193) connected to a Li-COR quantameter (Model Li-185). The photon fluence rate in all treatments was $350 \mu \mathrm{mol}$ photons $\mathrm{m}^{-2} \mathrm{~s}^{-1}$. Photosynthetic responses of the species were not inhibited, as previously reported by Ursi et al. (2003). To achieve this photon fluence rate, different quantities of tubes were utilized at each light quality (4 tubes for WH, 14 for GR, 6 for RD and 16 for $\mathrm{BL}$ ).

\section{Fertility and growth rate analysis}

Branch morphology and reproductive occurrences of tetrasporangia, spermatangial conceptacles or cystocarps were evaluated weekly throughout the experimental period. The differentiation of reproductive structure was assessed with a stereomicroscope, adding light quality filters to ensure uniform exposure of algae to light quality similar to that of the experimental chamber in order to avoid contamination of any white light flash throughout the experimental period. At the end of nine weeks, total $(\mathrm{T})$ and fertile $(\mathrm{F})$ lengths of tetrasporophytes and male gametophytes were measured in centimetres, starting from the basal portion of the branch. Considering each flask as a replicate, $\mathrm{T}$ and $\mathrm{F}$ were obtained from the sum of the lengths of four apices (for tetrasporophytes) and two apices (for male gametophytes) contained in each flask, totalizing one value of T, F, and fertility per flask, and this value was considered as replicate. Percentage of fertility data $(\mathrm{F} \%)$ were considered as $\mathrm{F} \%=(\mathrm{F} / \mathrm{T}) 100$ to obtain a percentage. The number of cystocarps on female gametophyte thalli was also evaluated after nine weeks. 

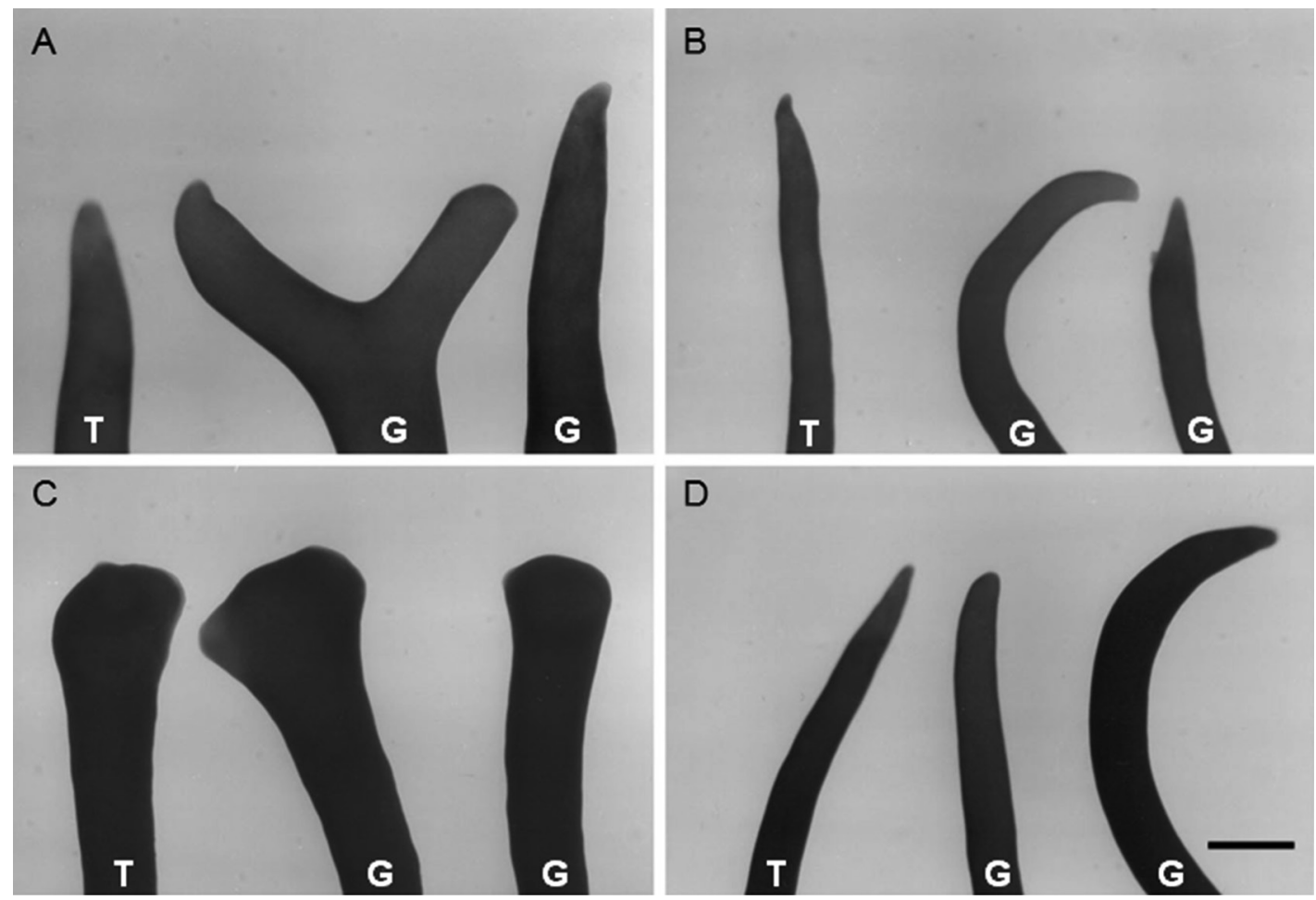

Fig. 2. - Morphology of apical tips of tetrasporophytes (T) and gametophytes $(\mathrm{G})$ of Gracilaria birdiae cultivated in 8L:16D under different light qualities. A. White, WH; B, Green, GR; C, Red, RD; and D, Blue, BL. The same morphological variations were observed in thalli cultivated in different light qualities under 14L:10D (data not shown). Bar scale: $1 \mathrm{~cm}$.

Fresh biomass was recorded weekly for nine weeks, and the growth rates (GRT) were estimated according to Lignell and Pedersén (1989): GRT $=\left[\left(\mathrm{W}_{\mathrm{f}} /\right.\right.$ $\left.\left.\mathrm{W}_{\mathrm{i}}\right)^{1 / \mathrm{t}}-1\right] 100$, where $\mathrm{W}_{\mathrm{f}}$ is the final measure, $\mathrm{W}_{\mathrm{i}}$ is the initial value of fresh weight, and $t$ is the time. GRT unit was $\%$ day $^{-1}$. Data for statistical analyses and comparisons were selected considering periods where these values remained constant regardless of the time. These were observed between the third and sixth weeks for all conditions and included the same quantity of days.

\section{Pigment analysis}

Pigment analysis was performed upon completion of the experimental period. Two hundred mg of tissue from tetrasporophytes and gametophytes cultivated in different treatments were ground with liquid nitrogen, followed by addition of $50 \mathrm{mM}$ phosphate buffer, $\mathrm{pH}$ 5.5. Crude extracts were centrifuged at $36000 \mathrm{~g}$ for 25 min to obtain phycobiliproteins. Chl $a$ was extracted after dissolving the pellet in $90 \%$ acetone and centrifuging at $12000 \mathrm{~g}$ for $15 \mathrm{~min}$ (Kursar et al. 1983a, modified by Plastino and Guimarães 2001).

Pigments were quantified in a spectrophotometer (HP 8452A), and concentrations of phycobiliproteins (allophycocyanin $[\mathrm{APC}]$, phycocyanin $[\mathrm{PC}]$ and phycoerythrin [PE]) and Chl $a$ were calculated according to Kursar et al. (1983a) and Jeffrey and Humphrey (1975), respectively.

\section{Statistical analysis}

Three-way analyses of variance (ANOVA) were performed on all data (independent variables: light quality, reproductive stage, and photoperiod). Homogeneity of variances (Cochran test) and normality were evaluated previously for ANOVA procedures. Where significant differences were detected, post hoc multiple comparisons were made using the Newman-Keuls test. Confidence interval $(\mathrm{CI})$ utilized was at $95 \%(\mathrm{p}<0.05)$ (Zar 1999). Fertility percent data were adjusted with arcsine data transformation. A Pearson correlation analysis was performed between growth rates and fertility values.

\section{RESULTS}

Apices of tetrasporophytes and gametophytes of Gracilaria birdiae cultivated in RD light became flattened after nine weeks (Fig. 2). Otherwise, those cultivated in $\mathrm{WH}, \mathrm{GR}$, and BL light remained filled, irrespective of photoperiod. In general, algae cultivated in WH and GR showed greater size and became more branched than those cultivated in RD or BL light (data not shown).

\section{Fertility}

Tetrasporangium differentiation was observed in thalli exposed to GR, RD, and BL light, irrespective of photoperiod. Otherwise, tetrasporangia were only observed in WH light when algae were cultivated in 8L:16D (Fig. 3). Under this photoperiod, the number of fertile tetrasporophytes among a total of 12 for each condition was 11 in WH, 8 in GR, 12 in RD, and 10 in BL. For the 14L:10D photoperiod, there were 10 in $\mathrm{GR}, 12$ in $\mathrm{RD}$, and 4 in BL. 

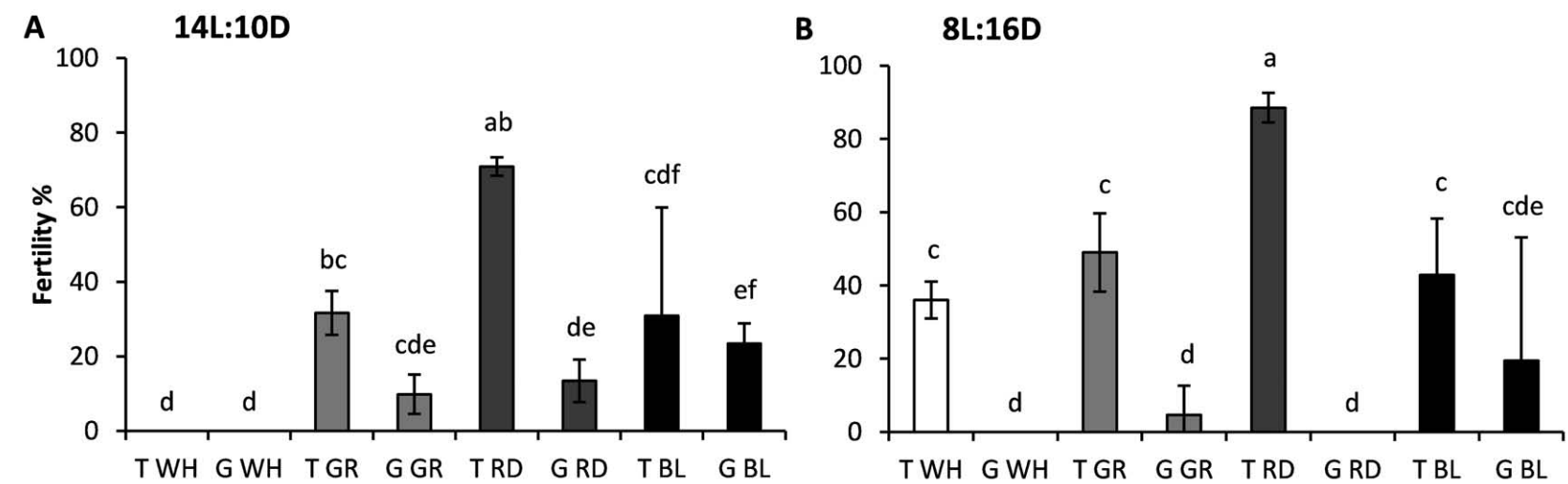

Fig. 3. - Total fertility (\%), considering tetrasporangia and spermatangial conceptacles on the thallus surface in relation to the total thallus length of tetrasporophytes (T) and gametophytes (G) of Gracilaria birdiae after nine weeks of cultivation in different light qualities (WH, white; GR, green; RD, red; and BL, blue) and photoperiods. A. 8L:16D; B. 14L:10D. Data are expressed as mean $\pm S D(n=3)$. Different letters indicate significant differences $(\mathrm{p}<0.05)$ by the Newman-Keuls test.

Neither spermatangial conceptacles nor cystocarps were observed in gametophytes cultivated in WH light, but they could be seen in other conditions (Fig. 3). Under a photoperiod of $8 \mathrm{~L}: 16 \mathrm{D}$, the number of fertile male individuals among a total of six for each condition was 1 in GR and 3 in the BL; for the 14L:10D photoperiod, there were 5 in GR, 4 in RD, and 6 in BL. Under a photoperiod of $8 \mathrm{~L}: 16 \mathrm{D}$, the number of individuals with cystocarps among a total of 6 for each condition was one individual with only one cystocarp in BL; for the 14L:10D photoperiod, there were 4 in GR with a total of 10 cystocarps and 2 in RD with a total of 8 cystocarps.

Fertility percentage was significantly influenced by light quality and reproductive stage, while no effects were observed as a consequence of photoperiodic treatments (Table 1). Tetrasporophytes cultivated in $\mathrm{RD}$ showed a higher fertility percentage than those cultivated in WH, GR, and BL light, irrespective of photoperiod (Fig. 3). After nine weeks, tetrasporangia occupied the thalli in greater numbers than sperma- tangial conceptacles in all culture conditions (Fig. 3), with the exception of three conditions in which the occupation was similar: BL (both photoperiods) and GR (14L:10D).

\section{Growth rates}

Growth rates were influenced by all analysed factors and all of their interactions. However, the main factor causing differences in this parameter was photoperiod ( $50.73 \%$ of variance), followed by light quality (30.56\% of variance). Although significant, interactive effects represented less than $8 \%$ of growth rate variations (Table 1). Tetrasporophytes showed higher GRT than gametophytes when cultivated under 14L:10D photoperiod in WH and GR light (Fig. 4). However, no differences were observed in other conditions. Algae cultivated in WH and GR light showed higher GRT than those cultivated in RD and BL, irrespective of photoperiod (Fig. 4). Compared with algae cultivated in WH and GR light, the growth rate in 14L:10D was

Table 1. - Results of a three-way ANOVA showing isolated and interactive effects among independent variables. Data were obtained for tetrasporophytes and gametophytes of Gracilaria birdiae cultivated under two photoperiods and four light qualities. GRT, growth rate; APC, allophycocyanin; PC, phycocyanin; PE, phycoerythrin; Chl $a$, chlorophyll $a$. Bold values indicate significant data with a confidence interval of $95 \%(\alpha<0.05) . \mathrm{n}=3$. * Regardless of time; ** Considering GRT obtained between the third and the sixth weeks.

\begin{tabular}{|c|c|c|c|c|c|c|c|c|}
\hline & & Photoperiod (1) & Light quality (2) & Repr. Stage (3) & $(1) \times(2)$ & $(1) \times(3)$ & $(2) \times(3)$ & $(1) \times(2) \times(3)$ \\
\hline \multirow{5}{*}{ Fertility* } & $\mathrm{df}$ & 1 & 3 & 1 & 3 & 1 & 3 & 3 \\
\hline & $\mathrm{F}$ & 1.28 & 78.46 & 14.22 & 21.83 & 2.63 & 8.51 & 0.38 \\
\hline & $\mathrm{p}$ & 0.27 & 0.00 & 0.00 & 0.00 & 0.07 & 0.00 & 0.77 \\
\hline & $\%$ Var & 1.01 & 61.63 & 11.17 & 17.15 & 2.07 & 6.68 & 0.30 \\
\hline & $\mathrm{F}$ & 182.8 & 108.0 & 35.45 & 12.11 & 4.37 & 3.77 & 6.85 \\
\hline \multirow{2}{*}{ GRT*** } & $\mathrm{p}$ & 0.00 & 0.00 & 0.00 & 0.00 & 0.04 & 0.02 & 0.00 \\
\hline & $\%$ Var & 51.73 & 30.56 & 10.03 & 3.43 & 1.24 & 1.07 & 1.94 \\
\hline \multicolumn{9}{|c|}{$\begin{array}{l}\text { Pigments } \\
\text { Concentration }\left(\mathrm{mg} \mathrm{g} \mathrm{FW}^{-1}\right)\end{array}$} \\
\hline \multirow{3}{*}{ APC } & $\mathrm{F}$ & 0.42 & 74.49 & 4.88 & 3.25 & 4.64 & 0.09 & 8.82 \\
\hline & $\mathrm{p}$ & 0.52 & 0.00 & 0.03 & 0.03 & 0.04 & 0.96 & 0.00 \\
\hline & $\%$ Var & 0.44 & 77.12 & 5.05 & 3.36 & 4.81 & 0.10 & 9.13 \\
\hline \multirow{4}{*}{$\mathrm{PC}$} & $\mathrm{F}$ & 163.66 & 242.12 & 14.76 & 1.03 & 2.59 & 0.40 & 11.99 \\
\hline & $\mathrm{p}$ & 0.00 & 0.00 & 0.00 & 0.39 & 0.12 & 0.76 & 0.00 \\
\hline & $\%$ Var & 37.49 & 55.46 & 3.38 & 0.24 & 0.59 & 0.09 & 2.75 \\
\hline & $\mathrm{F}$ & 550.73 & 1123.52 & 7.65 & 72.07 & 57.91 & 14.87 & 58.09 \\
\hline \multirow{3}{*}{$\mathrm{PE}$} & $\mathrm{p}$ & 0.00 & 0.00 & 0.01 & 0.00 & 0.00 & 0.00 & 0.00 \\
\hline & $\%$ Var & 29.22 & 59.61 & 0.41 & 3.82 & 3.07 & 0.79 & 3.08 \\
\hline & $\mathrm{F}$ & 314.85 & $\mathbf{5 5 . 3 7}$ & 10.46 & 5.64 & 7.13 & 9.81 & 2.06 \\
\hline \multirow{2}{*}{ Chl $a$} & $\mathrm{p}$ & 0.00 & 0.00 & 0.00 & 0.00 & 0.01 & 0.00 & 0.12 \\
\hline & $\%$ Var & 77.68 & 13.66 & 2.58 & 1.39 & 1.76 & 2.42 & 0.51 \\
\hline
\end{tabular}




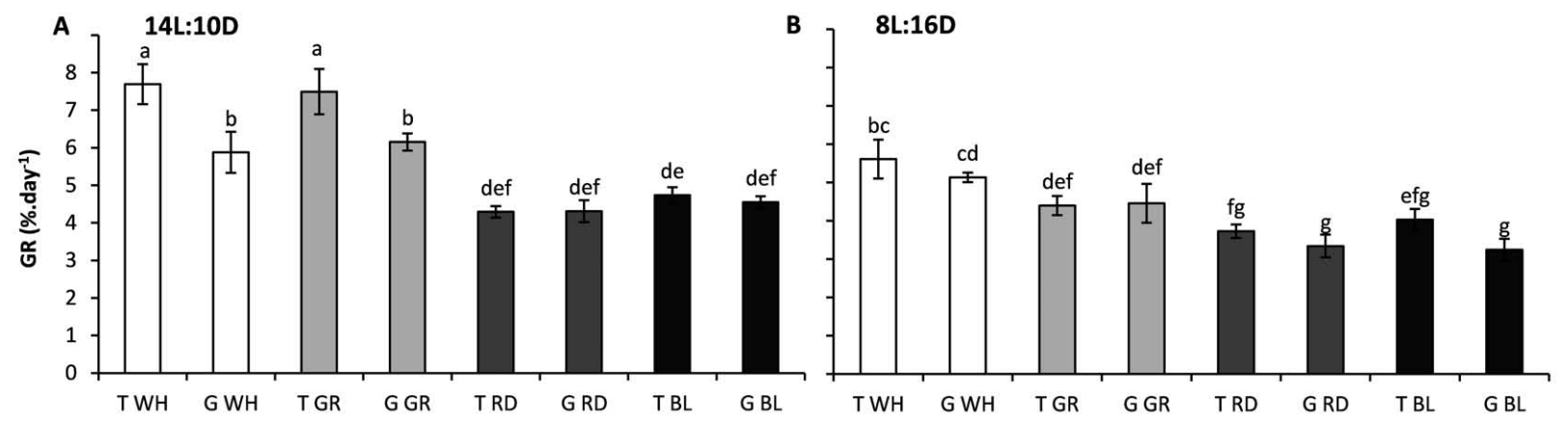

Fig. 4. - Growth rates (GRT) expressed as \% day ${ }^{-1}$ of tetrasporophytes (T) and gametophytes (G) of Gracilaria birdiae cultivated in different light qualities [white (WH), green (GR), red (RD), and blue (BL)] and two photoperiods. A, 14L:10D; B, 8L:16D. Data were obtained from the third to the sixth weeks. Data are expressed as mean $\pm \mathrm{SD}(\mathrm{n}=3)$. Different letters indicate significant differences $(\mathrm{p}<0.05)$ by the Newman-Keuls test.

higher than that observed in $8 \mathrm{~L}: 16 \mathrm{D}$, whereas algae cultivated in RD and BL showed a similar GRT in both photoperiods (Fig. 4). In 14L:10D, the GRTs of algae cultivated in WH and GR light were similar, whereas in $8 \mathrm{~L}: 16 \mathrm{D}$, the GRTs were higher in WH than in GR light.

Tetrasporangium differentiation and growth rates showed a significant negative correlation $(p<0.05)$ in algae cultivated in GR and RD light (8L:16D: GR, r=0.67 ; RD, $\mathrm{r}=-0.78$; and 14L:10D: GR, $\mathrm{r}=-0.63$; RD, $\mathrm{r}=-0.82$ ). However, differentiation of spermatangial conceptacles or cystocarps showed no correlation with growth rates in any condition $(\mathrm{p}>0.05)$.

\section{Pigment content}

Light quality was the main factor that promoted variation in the content of accessory pigments in $G$. birdiae. More than $50 \%$ of variations in APC, PE and $\mathrm{PC}$ content were observed as a result of these treatments (Table 1). PE and PC contents were also influenced by the isolated photoperiod factor. Algae cultivated in different light qualities showed higher $\mathrm{PC}$ and PE contents in the 8L:16D photoperiod than algae cultivated in 14L:10D (Fig. 5). Considering each photoperiod, algae cultivated in BL showed higher PC and $\mathrm{PE}$ contents than those of algae exposed to $\mathrm{WH}$, GR, and RD light. In 14L:10D and 8L:16D, PC and $\mathrm{PE}$ contents of algae cultivated in GR were higher than those under WH and RD. Furthermore, in 8L:16D, tetrasporophytes exposed to GR and RD showed higher $\mathrm{PC}$ content than tetrasporophytes cultivated in WH light. In general, APC content was also higher in BL and GR-cultivated samples. The highest amount was recorded for gametophytes cultivated in $8 \mathrm{~L}: 16 \mathrm{D}$ and tetrasporophytes cultivated in $14 \mathrm{~L}: 10 \mathrm{D}$, both of which showed higher APC content under BL light than either gametophytes or tetrasporophytes exposed to WH, GR, and RD under both photoperiods (Fig. 5).

Photoperiod was the principal factor affecting Chl $a$ content, although this pigment content was also influenced by light quality (Table 1). Algae cultivated in $8 \mathrm{~L}: 16 \mathrm{D}$ showed a higher $\mathrm{Chl} a$ content than algae cultivated in $14 \mathrm{~L}: 10 \mathrm{D}$, irrespective of light quality and reproductive stage, with the exception of tetrasporophytes exposed to $\mathrm{WH}$, which showed similar Chl $a$ contents in both photoperiods (Fig. 5). Individuals cultivated in $8 \mathrm{~L}: 16 \mathrm{D}$ showed a higher content of $\mathrm{Chl}$ $a$ when cultivated in GR and BL than when cultivated in $\mathrm{WH}$ and RD, whereas in 14L:10D only tetrasporophytes cultivated in GR had a higher Chl $a$ content than those cultivated in WH and RD.

Reproductive stages did not seem to cause many significant variations in the pigment content of G. birdiae. This factor caused only a few variations in APC, $\mathrm{PC}$ and PE concentrations, i.e. only $5.05 \%, 3.38 \%$ and $0.41 \%$ of variation (Table 1 ). With few exceptions, detailed analyses showed the absence of pigment content differences between tetrasporophytes and gametophytes cultivated in the same conditions: i) in GR, tetrasporophytes had higher Chl $a$ content than gametophytes (14L:10D) and ii) in BL, tetrasporophytes had higher $\mathrm{APC}, \mathrm{PC}$ and $\mathrm{PE}$ contents than gametophytes (14L:10D), while gametophytes had higher APC, PC and PE contents than tetrasporophytes (8L:16D) (Fig. $5)$. Furthermore, interaction of factors was also significant for causing pigment content variations, although the highest percentage of variance was observed for interaction of photoperiod and reproductive stage (4.81\%). Other factor interactions were reported, mainly involving APC, PE and Chl $a$ contents (Table 1).

\section{DISCUSSION}

In this study, it is shown that both light quality and photoperiod influenced the differentiation of reproductive structures in Gracilaria birdiae. A stimulatory effect was mainly observed under RD light, since all tetrasporophytes showed changes in apical tips, as well as a higher percentage of fertility. Tetrasporangium development, as well as apical tip changes, could be regulated by red/far-red light phytochrome-like photoreceptors because these modifications were observed with RD light, although to confirm this hypothesis, it is necessary to show a reversion of the response by farred light. Phytochrome-like photoreceptors have been identified in different algal species, including red macroalgae (López-Figueroa et al. 1989). These possible photoreceptors in G. birdiae can also be more active in short-day conditions (8L:16D), in which the highest percentage of tetrasporangium occurred. Considering its geographical distribution, G. birdiae occurs under 

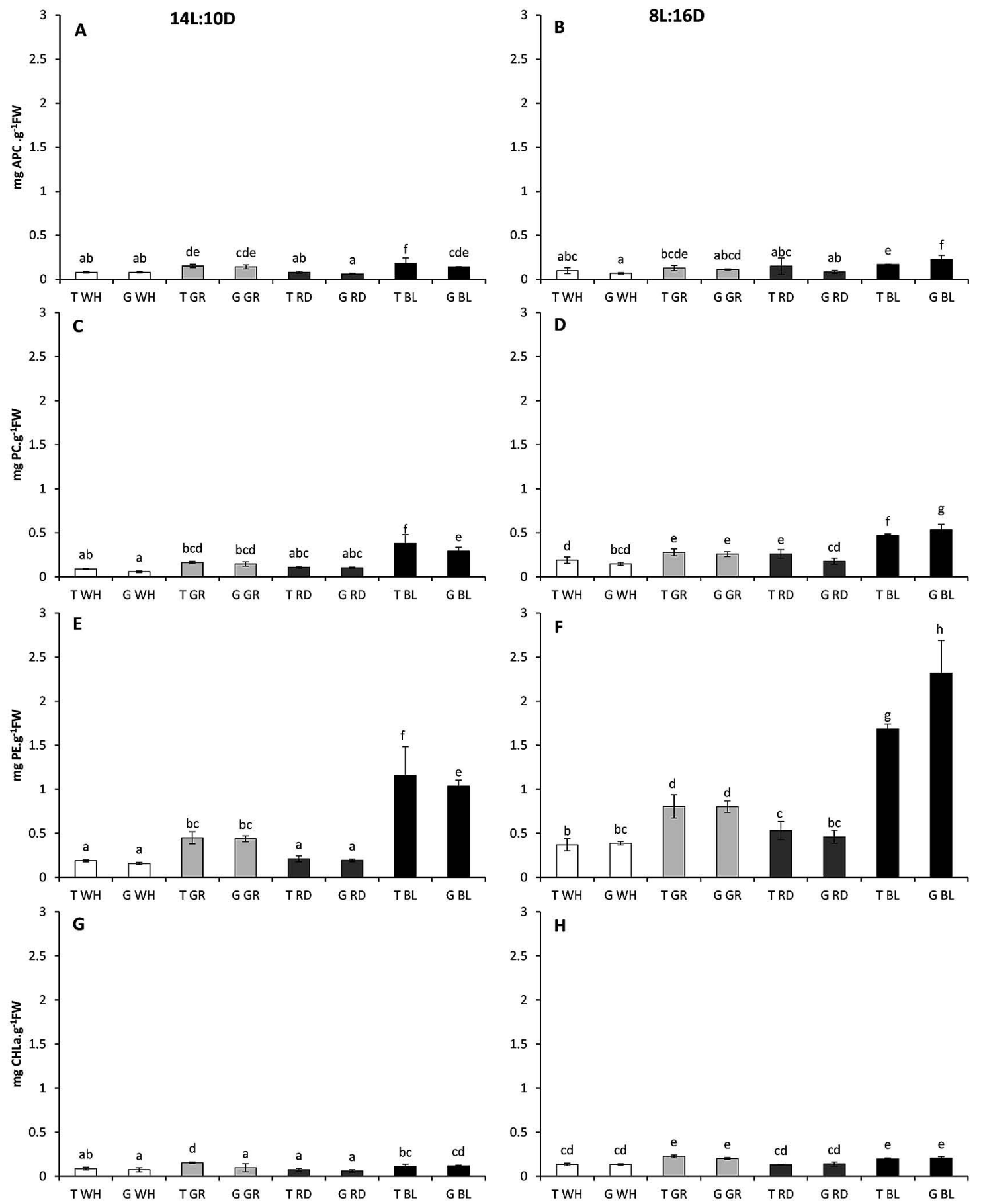

Fig. 5. - Pigment concentration (APC, allophycocyanin; PC, phycocyanin; PE, phycoerythrin; and Chl $a$, chlorophyll $a$ ) expressed as mg g-1 FW of tetrasporophytes $(\mathrm{T})$ and gametophytes $(\mathrm{G})$ of Gracilaria birdiae cultivated under different light qualities [white $(\mathrm{WH})$, green $(\mathrm{GR})$, red (RD), and blue (BL)] and two different photoperiods. A, APC and 14L:10D; B, APC and 8L:16D; C, PC and 14L:10D; D, PC and 8L:16D; E, PE and 14L:10D; F, PE and 8L:16D; G, Chl $a$ and 14L:10D; H, Chl $a$ and 8L:16D. Data are expressed as mean \pm SD (n=3). Different letters indicate significant differences $(\mathrm{p}<0.05)$ by the Newman-Keuls test.

different photoperiods, within a narrow range of 10.8 to 13.9 hours of light by day, depending on the latitudinal position. Thus, the photoperiod can influence reproductive status of tetrasporophytic thalli, even if not exposed exactly to $8 \mathrm{~L}: 16 \mathrm{D}$ in nature. Under these circumstances, the photoperiod could explain the frequency variation of reproductive stages observed in natural populations of $G$. birdiae by Carneiro et al. (2011). These authors observed higher tetrasporophyte percentages during the winter months when photoperiods are shorter than in summer months.

The high occurrence of tetrasporangia in G. birdiae was negatively correlated with GRT, as previously observed in other Gracilaria species, in which lower GRTs were reported in both fertile tetrasporophytes (Santelices and Varela 1995) and cystocarpic plants (Guimarães et al. 1999). These results could be related to an energy transfer of growth to reproductive structure differentia- 
tion, and in G. birdiae it was essentially stimulated by RD light. This light quality also promoted sorus differentiation in Dictyota dichotoma, as well as lower GRT, as reported by Müller and Clauss (1976). These authors suggested that these responses could have also occurred due to the absence of BL spectra, resulting in a reduction in photosynthetic rates. Moreover, according to the action spectra for photosynthesis in red algae, photosynthetic activity is lower under BL than under $\mathrm{RD}$, owing to the low efficiency of electron transport in photosystem II under BL light because most chlorophyll (about $85 \%$ ) in red algae is located in photosystem I (Lüning and Dring 1985, Grzymski et al. 1997). By this logic, the absence of BL spectra could stimulate the investment of light energy for reproduction instead of photosynthesis and, consequently, growth in tetrasporophytes of $G$. birdiae. Otherwise, cystocarps and spermatangial conceptacles were not differentiated in sufficient amounts to promote the decrease of GRT, and their differentiation could not be related to any specific wavelength. The higher fertility of tetrasporophytes in comparison with gametophytes agrees with the phenology of $G$. birdiae (Carneiro et al. 2011). Moreover, tetrasporophytes were much more abundant and efficient at occupying environmental niches than gametophytes, indicating a greater ability to respond to environmental signals as inductors of fertility, in turn resulting in higher propagation of the species.

Growth rates of Gracilaria birdiae cultivated in GR light were similar to those observed in algae subjected to WH light and 14L:10D. This response could have resulted from the absorption of green light by phycobiliproteins, which transferred the collected energy to essential pigments, thereby sustaining the performance of the photosynthetic apparatus (Lüning and Dring 1985). Similar GRTs in GR and WH lights were also observed in Gracilaria sp. (Beer and Levy 1983).

The response of photoacclimation in Gracilaria birdiae to GR light can also be related to a change in phycobilisomal structure, as reported in GR-acclimated Phormidium sp., in which phycobilisomes were twice those observed in RD light (Ohki and Fujita 1992). Phycobiliproteins in phycobilisomes are usually connected by photosystem II, and they can carry energy to photosystem I, thus optimizing energy absorption and increasing photosynthetic rates. In photosystem I, an elevated content of carotenoids can play a similar role (Figueroa et al. 1995a). The increase of phycobiliproteins that occurred in G. birdiae cultivated under BL and GR light could be related to improved energy absorption, which is transferred to Chl $a$ to make up for the absence of other light qualities that are usually absorbed by chlorophyll. The same observation was shown in Porphyra leucosticta (Tsekos et al. 2002). Additional evidence of this optimization of light energy and possible rearrangement of phycobilisome structure in G. birdiae was achieved by the same proportion of pigment content that could be seen in algae cultivated in WH, GR, and RD light, irrespective of photoperiod, although the amounts of these pigments were higher in GR-cultivated samples. This aspect shows an evident induction of increasing phycobiliproteins and Chl $a$ in $G$. birdiae cultivated in GR light.
While GR light was efficiently utilized in G. birdiae, BL light hindered its optimal development, but this light quality was also essential for maximal productivity of other alga species, such as brown algae, stimulating saturated photosynthesis as a result of the transport of inorganic carbon from seawater to chloroplasts (Forster and Dring 1994). For G. birdiae, however, any kind of response related to the positive effects of BL could be compromised by continuous exposure, and the absence of other essential light qualities minimized any positive effect. Higher GRTs under GR light than under RD or BL light were previously reported in Palmaria palmata (Sagert and Schubert 1995) and Halymenia floresii (Godínez-Ortega et al. 2008). In the latter case, it was suggested that the activity of Chl $a$, which accumulated under GR, increased the efficiency of light absorption. These types of response to BL and GR light could be considered as physiological acclimation in G. birdiae, similarly to Mazzaella laminarioides (Marquardt et al. 2010). These authors showed that macroalgae can follow physiological versus morphological photoacclimation strategies in response to variations in both irradiance and light quality (Marquardt et al. 2010).

The accessory pigment synthesis in Gracilaria birdiae was stimulated by BL light. This response could be controlled by cryptochrome-like photoreceptors, in a manner similar to that suggested for the inhibition of erect axis development in Scytosiphon lomentaria (Dring and Lüning 1975). Moreover, G. birdiae could have photoacclimated under BL, resulting in a package effect, as reported in Porphyra umbilicalis (Figueroa et al. 1995a). The package effect is related to the absorption of Chl $a$ content and can be attributed to four factors: (1) changes in cell size, shape, or morphology; (2) changes in chloroplast structure; (3) changes in the degree of stacking of thylakoid membranes; and (4) changes in optical properties in thylakoid membranes (Berner et al. 1989). For G. birdiae, we have suggested a proportionally greater increase of the external part of phycobilisome in $\mathrm{BL}$ in contrast to $\mathrm{RD}$, thus increasing the potential for a possible package effect, much like $P$. umbilicalis under BL light. Considering the high $\mathrm{PE}$ and PC contents in G. birdiae, a higher BL-enhanced production in pigment proteins is suggested, similar to Chondrus crispus (López-Figueroa 1991) and P. umbilicalis (Figueroa et al. 1995a). BL could also stimulate the accumulation of nitrogen compounds in G. birdiae, such as PE and PC, and the resultant higher density of phycobilisomes under BL than that observed under RD and GR, as reported in P. leucosticta (Tsekos et al. 2002). Because of the relatively rapid accumulation of PE, this photosynthetic pigment has been suggested as an $\mathrm{N}$ store compound, as in cyanobacteria and red macroalgae (Lapointe et al. 1984, Figueroa et al. 1995a).

Since the condition of constant light quality is unusual to its development, Gracilaria birdiae could have utilized its possible photoprotection mechanisms to survive under these conditions. Two examples can be given. First, the high amount of PE in G. birdiae cultivated under BL could act as a system of energy dissipation, together with a possible xanthophyll cycle, 
a phenomenon which has been related to energy dissipation (Demmig-Adams 2003). The occurrence of this cycle in G. birdiae was suggested by Ursi et al. (2003), and an incomplete xanthophyll cycle was proposed for G. tenuistipitata by Barufi et al. (2011). A second photoprotective mechanism involves the position of different phycobiliproteins in the phycobilisome. $G$. birdiae, in general, showed a lower variation of APC content than that of other phycobiliproteins (PC and $\mathrm{PE}$ ), indicating that APC is located in the innermost part of the phycobilisome, in accordance with phycobilisomal models suggested by Gantt (1990). Thus, whereas APC is protected against degradation by any specific wavelength, the other more externally located phycobiliproteins are at higher risk for degradation by any given wavelength.

The changes in apical tips of Gracilaria birdiae were probably a consequence of continuous RD. This is a typical case of morphological photoacclimation, such as those presented by Marquardt et al. (2010) for Gracilaria chilensis. However, we cannot directly associate these changes with RD because this condition also increased tetrasporangium development. These modifications in apical portions of the thalli could be an effect of interaction between radiation and reproductive status. In addition, a decrease in GRT was observed in this condition. It is not possible to ascribe a deleterious effect to RD because no alga mortality was observed, and mortality was considered imperative to characterize a deleterious effect (Gerard 1997). Nonetheless, further studies are required to clarify this issue, as well as any kind of reversibility of morphological changes, such as the transfer to algae to less stressful conditions after treatment under RD light.

Based on the light qualities tested, we provide indications of physiological mechanisms which allow improvements of possible mariculture and commercial exploitation approaches of $G$. birdiae. Although the photoperiod 8L:16D is not achieved in environmental distribution of the species, it is interesting to test the physiological capacity in broader photoperiodic conditions than those in nature to evaluate the potential capacity for a possible biotechnological application. Therefore, we suggest to test also usage of 10L:14D following the algal distribution pattern in future experiments. Our results for $8 \mathrm{~L}: 16 \mathrm{D}$ can be analysed as indications of short-day regulated responses. In addition, we have indicated RD light quality as a possible inductor of fertility to produce tetraspores, which could be used as seedlings. Otherwise, we have shown the negative effects of BL light exposure on GRT of $G$. birdiae. However, if the aim is to achieve high phycoerythrin content, the exposure to this light quality could be a good alternative. Furthermore, a combination of different wavelengths could allow better economic resource exploitation.

\section{ACKNOWLEDGEMENTS}

This research was supported by the São Paulo Research Foundation (FAPESP, 98/11943-1; 02/04987$0)$ and the Brazilian National Council for Scientific and
Technological Development (CNPq; 300148/93-3). We thank Rosário Petti for providing technical support.

\section{REFERENCES}

Armisén R. 1995. World-wide use and importance of Gracilaria. J. Appl. Phycol. 7: 231-243. http://dx.doi.org/10.1007/BF00003998

Ayres-Ostrock L.M., Plastino E.M. 2014a. Effects of short-term exposure to ultraviolet-B radiation on photosynthesis and pigment content of red (wild types), greenish-brown, and green strains of Gracilaria birdiae (Gracilariales, Rhodophyta). J. Appl. Phycol. 26: 867-879. http://dx.doi.org/10.1007/s10811-013-0131-3

Ayres-Ostrock L.M., Plastino E.M. 2014b. Effects of UV-B radiation on growth rates, pigment content and ultrastructure of red (wild type), greenish-brown and green strains of Gracilaria birdiae (Gracilariales, Rhodophyta). Eur. J. Phycol. 49: 197-212. http://dx.doi.org/10.1080/09670262.2014.904931

Barufi J.B., Korbee N., Oliveira M.C., et al. 2011. Effects of N supply on the accumulation of photosynthetic pigments and photoprotectors in Gracilaria tenuistipitata (Rhodophyta) cultured under UV radiation. J. Appl. Phycol. 23: 457-466. http://dx.doi.org/10.1007/s10811-010-9603-x

Beer S., Levy I. 1983. Effects of photon fluence rate and light spectrum composition on growth, photosynthesis and pigment relations in Gracilaria sp. J. Phycol. 19: 516-522. http://dx.doi.org/10.1111/j.0022-3646.1983.00516.x

Berner T., Dubinsky Z., Wyman K., et al. 1989. Photoadaptation and the "package" effect in Dunaliella tertiolecta (Chlorophyceae). J. Phycol. 25: 70-78. http://dx.doi.org/10.1111/j.0022-3646.1989.00070.x

Carneiro M.A.A., Marinho-Soriano E., Plastino E.M. 2011. Phenology of an agarophyte Gracilaria birdiae Plastino and E.C. Oliveira (Gracilariales, Rhodophyta) in Northeastern Brazil. Rev. Bras. Farmacogn. 21: 317-322. http://dx.doi.org/10.1590/S0102-695X2011005000067

Costa V.L., Plastino E.M. 2001. Histórico de vida de espécimens selvagens e variantes cromáticas de Gracilaria sp. (Gracilariales, Rhodophyta). Rev. Brasil. Bot. 24: 491-500.

Costa V.L., Plastino E.M. 2011. Color inheritance and pigment characterization of red (wild-type), greenish-brown, and green strains of Gracilaria birdiae (Gracilariales, Rhodophyta). J. Appl. Phycol. 23: 599-605. http://dx.doi.org/10.1007/s10811-010-9642-3

Costa E.S., Plastino E.M., Petti R., et al. 2012. The Gracilariaceae germoplasm bank of the University of São Paulo, Brazil a DNA barcoding approach. J. Appl. Phycol. 1: 1-11.

Demmig-Adams B. 2003. Linking the xanthophyll cycle with thermal energy dissipation. Photosynt. Res. 76: 73-80. http://dx.doi.org/10.1023/A:1024902927403

Dring M.J. 1988. Photocontrol of development in algae. Ann. Rev. Plant. Physiol. Plant. Mol. Biol. 39: 157-174. http://dx.doi.org/10.1146/annurev.pp.39.060188.001105

Dring M.J., Lüning K. 1973. Induction of two-dimensional growth and hair formation by blue light in the brown alga Scytosiphon lomentaria. Z. Pflanzenphysiol. Bd. 75: 107-117. http://dx.doi.org/10.1016/S0044-328X(75)80107-3

Dring M.J., Lüning K. 1975. A photoperiodic response mediated by blue light in the brown algae Scytosiphon lomentaria. Planta (Berl.) 125: 25-32. http://dx.doi.org/10.1007/BF00388870

Falkowski P.G., LaRoche J. 1991. Acclimation to spectral irradiance in algae. J. Phycol. 27: 8-14. http://dx.doi.org/10.1111/j.0022-3646.1991.00008.x

Figueroa F.L., Aguilera J., Niell F.X. 1995a. Red and blue light regulation of growth and photosynthetic metabolism in Porphyra umbilicalis (L.) Kützing (Bangiales, Rhodophyta). Eur. J. Phycol. 30: 11-18. http://dx.doi.org/10.1080/09670269500650761

Figueroa F.L., Aguilera J., Jiménez C., et al. 1995b. Growth, pigment synthesis and nitrogen assimilation in the red alga Porphyra umbilicalis (L.) Kützing (Bangiales, Rhodophyta) under blue and red light. Sci. Mar. 59: 9-20.

Forster R.M., Dring M.J. 1994. Influence of blue light on the photosynthetic capacity of marine plants from different taxonomic, ecological and morphological groups. Eur. J. Phycol. 29: 21-27. http://dx.doi.org/10.1080/09670269400650441

Franklin L.A., Kräbs G., Kuhlenkamp R. 2001. Blue light and UV-A 
radiation control the synthesis of mycosporine-like amino acids in Chondrus crispus (Florideophyceae). J. Phycol. 37: 257-270. http://dx.doi.org/10.1046/j.1529-8817.2001.037002257.x

Gantt E. 1990. Pigmentation and photoacclimation. In: Cole K.M., Sheat R.G. (eds), Biology of the red algae. Cambridge University Press, Cambridge, pp 203-219.

Gerard V.A. 1997. Environmental stress during early development of kelp sporophytes (Laminaria saccharina): how long do effects persist? J. Appl. Phycol. 9: 5-9. http://dx.doi.org/10.1023/A:1007952030505

Godínez-Ortega J.L., Snoeijs P., Robledo D., et al. 2008. Growth and pigment composition in the red alga Halymenia floresi cultured under different light qualities. J. Appl. Phycol. 20: 253-260. http://dx.doi.org/10.1007/s10811-007-9241-0

Grzymski J., Johnsen G., Sakshug E. 1997. The significance of intracellular self-shading on the bio-optical properties of brown, red and green macroalgae. J. Phycol. 33: 408-414 http://dx.doi.org/10.1111/j.0022-3646.1997.00408.x

Guimarães M., Plastino E.M., Oliveira E.C. 1999. Life history, reproduction and growth of Gracilaria domingensis (Gracilariales, Rhodophyta) from Brazil. Bot. Mar. 42: 481-486. http://dx.doi.org/10.1515/BOT.1999.055

Jeffrey W., Humphrey G.F. 1975. New spectrophotometric equations for determining chlorophylls $a, b, c 1$ and $c 2$ in higher plants, algae and natural phytoplankton. Biochem. Physiol. Pflanzen. (BPP) Bd. 167: 191-194.

Kursar T.A., Van Der Meer J., Alberte R.S. 1983a. Light-harvesting system of the red alga Gracilaria tikvahiae. I. Biochemical analyses of pigment mutations. Plant Physiol. 73: 353-360. http://dx.doi.org/10.1104/pp.73.2.353

Kursar T.A., Van Der Meer J., Alberte R.S. 1983b. Light-harvesting system of the red alga Gracilaria tikvahiae. II. Phycobilissome characteristics of pigment mutants. Plant Physiol. 73: 361-369. http://dx.doi.org/10.1104/pp.73.2.361

Lapointe B.E., Dawes C.J., Tenore K.R. 1984. Interactions between light and temperature on the physiological ecology of Gracilaria tikvahiae (Gracilariales, Rhodophyta). II. Nitrate uptake and levels of pigments and chemical constituents. Mar. Biol. 80: $171-178$. http://dx.doi.org/10.1007/BF02180184

Lignell A., Pedersén M. 1989. Agar composition as a function of morphology and growth rate. Studies on some morphological strains of Gracilaria secundata and Gracilaria verrucosa (Rhodophyta). Bot. Mar. 32: 219-227. http://dx.doi.org/10.1515/botm.1989.32.3.219

López-Figueroa F. 1991. Red, blue and green photoreceptors controlling chlorophyll, biliprotein and total protein synthesis in the red alga Chondrus crispus. Br. Phycol. J. 26: 383-392. http://dx.doi.org/10.1080/00071619100650351

López-Figueroa F., Niell F.X. 1989. Red-light and blue-light photoreceptors controlling chlorophyll $a$ synthesis in the red alga Porphyra umbilicalis and in the green alga Ulva rigida. Physiol. Plantarum. 76: 391-397. http://dx.doi.org/10.1111/j.1399-3054.1989.tb06209.x

López-Figueroa F., Niell F.X. 1991. Photocontrol of chlorophyll and biliprotein synthesis in seaweeds: possible photoreceptors and ecological considerations. Sci. Mar. 55: 519-527.

López-Figueroa F., Lindemann P., Braslavsky S.E., et al. 1989. Detection of a phytochrome -like protein in macroalgae. Bot. Acta. 102: 178-180 http://dx.doi.org/10.1111/j.1438-8677.1989.tb00089.x

Lourenço S.O., Vieira A.A.H. 2004. Culture collections of microalgae in Brazil: progress and constraints. Nova Hedwigia 79: 149-173. http://dx.doi.org/10.1127/0029-5035/2004/0079-0149

Lüning K. 1992. Day and night kinetics of growth rate in green, brown and red seaweeds. J. Phycol. 28: 794-803. http://dx.doi.org/10.1111/j.0022-3646.1992.00794.x

Lüning K., Dring, M.J. 1973. The influence of light quality on the development of the brown algae Petalonia and Scytosiphon. Br. Phycol. J. 8: 333-338. http://dx.doi.org/10.1080/0007161730065036

Lüning K., Dring M.J. 1985. Action spectra and spectral quantum yield of photosynthesis in marine macroalgae with thin and thick thalli. Mar. Biol. 87: 119-129.
http://dx.doi.org/10.1007/BF00539419

Marquardt R., Schubert H., Varela D.A., et al. 2010. Light acclimation strategies of three commercially important red algal species. Aquaculture 299: 140-148. http://dx doi.org/10.1016/j.aquaculture.2009.11.004

Müller S., Clauss H. 1976. Aspects of photomorphogenesis in the brown alga Dictyota dichotoma. Zeitschrift. fur Pflanzen. 78: 461-465. http://dx.doi.org/10.1016/S0044-328X(76)80095-5

Monro K., Poore A.G.B. 2005. Light quantity and quality induce shade-avoiding plasticity in marine macroalgae. J. Evol. Biol. 18: 426-435. http://dx.doi.org/10.1111/j.1420-9101.2004.00826.x

Ohki K., Fujita Y. 1992. Photoregulation of phycobilisome structure during complementary chromatic adaptation in the marine cyanophyte Phormidium sp. C86. J. Phycol. 28: 803-808 http://dx.doi.org/10.1111/j.0022-3646.1992.00803.x

Plastino E.M., Guimarães M. 2001. Diversidad intraespecífica. In: Alveal K., Antezana T. (eds) Sustentabilidad de la biodiversidad. Universidad de Concepción, Concepción, pp. 19-27.

Plastino E.M., Oliveira E.C. 1990. Crossing experiments as an aid to the taxonomic recognition of the agarophyte alga Gracilaria (Rhodophyta, Gigartinales). In: Oliveira E.C., Kautsky N. (eds) Cultivation of Seaweeds in Latin American. Universidade de São Paulo, São Paulo, pp. 127-133.

Plastino E.M., Oliveira E.C. 2002. Gracilaria birdiae (Gracilariales, Rhodophyta), a new species from the tropical south American Atlantic with a terete frond and deep spermatangial conceptacles. Phycologia 41: 389-396. http://dx.doi.org/10.2216/10031-8884-41-4-389.

Plastino E.M., Ursi S., Fujii M.T. 2004. Color inheritance, pigment characterization, and growth of a rare light green strain of Gracilaria birdiae (Gracilariales, Rhodophyta). Phycol. Res. 52: $45-52$. http://dx.doi.org/10.1111/j.1440-1835.2004.tb00314.x

Rüdiger W., López-Figueroa F. 1992. Photoreceptors in algae. Ann. Rev. Photochem. Photobiol. 55: 949-954. http://dx.doi.org/10.1111/j.1751-1097.1992.tb08542.x

Sagert S., Schubert H. 1995. Acclimation of the photosynthetic apparatus of Palmaria palmata (Rhodophyta) to light qualities that preferentially excite photosystem I or photosystem II. J. Phycol. 31: 547-554. http://dx.doi.org/10.1111/j.1529-8817.1995.tb02548.x

Santelices B., Varela D. 1995. Regenerative capacity of Gracilaria fragments: effects of size, reproductive state and position along the axis. J. Appl. Phycol. 7: 501-506. http://dx.doi.org/10.1007/BF00003935

Talarico L., Maranzana G. 2000. Light and adaptive responses in red macroalgae: an overview. J. Photochem. Photobiol. B. Biol. 56: $1-11$. http://dx.doi.org/10.1016/S1011-1344(00)00046-4

Thirb H.H., Benson-Evans K. 1983. The effect of different light intensities and wavelengths on carpospore germination and the apical tips of the red alga Lemanea Bory (1808). Nova Hedwigia 37: 669-682.

Tsekos I., Niell F.X., Aguilera J., et al. 2002. Ultrastructure of the thallus stage of Porphyra leucosticta (Rhodophyta) grown in red, blue and green light. Phycol. Res. 50: 251-264. http://dx.doi.org/10.1111/j.1440-1835.2002.tb00158.x

Ursi S., Plastino E.M. 2001. Crescimento in vitro de linhagens de coloração vermelha e verde clara de Gracilaria birdiae (Gracilariales, Rhodophyta) em dois meios de cultura: análise de diferentes estádios reprodutivos. Rev. Brasil. Bot. 24: 585-592.

Ursi S., Pedersén M., Plastino E.M., et al. 2003. Intraspecific variation of photosynthesis, respiration and photoprotective carotenoids in Gracilaria birdiae (Gracilariales, Rhodophyta). Mar. Biol. 142: 997-1007.

Ursi S., Guimarães M., Plastino E.M. 2008. Deleterious effects of TRIS buffer on growth rates and pigment content of Gracilaria birdiae Plastino and E.C. Oliveira (Gracilariales, Rhodophyta). Acta. Bot. Bras. 22: 891-896. http://dx.doi.org/10.1590/S0102-33062008000300024

Zar J.H. 1999. Biostatistical analysis. Prentice Hall, Upper Saddle River, New Jersey. 